\title{
Field and Agroinoculation Screening for Resistance against MYMV in Mungbean Backcross Populations
}

\author{
B. Madhumitha1, K. Eraivan Arutkani Aiyanathan², \\ M. Kanimoli Mathivathana ${ }^{3}$ and M. Sudha ${ }^{4 *}$ \\ ${ }^{1}$ Department of Plant Pathology, Agricultural College and Research Institute, \\ Madurai, Tamil Nadu, India \\ ${ }^{2}$ Agricultural College and Research Institute, Killikulam, Tamil Nadu, India \\ ${ }^{3}$ Department of Plant Breeding and Genetics, Agricultural College and Research Institute, \\ Madurai, Tamil Nadu, India \\ ${ }^{4}$ Department of Plant Biotechnology, Centre for Plant Molecular Biology and biotechnology, \\ Tamil Nadu Agricultural University, Coimbatore, Tamil Nadu, India \\ *Corresponding author
}

\section{A B S T R A C T}

\section{Keywords}

Mungbean

[Vigna radiata $(\mathrm{L}$.

Wilczek]

MYMV disease

Article Info

Accepted:

17 March 2019

Available Online:

10 April 2019
Mungbean [Vigna radiata (L.) Wilczek] known as green gram is one of the major fastgrowing, warm-season crop that is primarily cultivated in developing countries of Asia. The production of mungbean is severely constrained by mungbean yellow mosaic virus (MYMV) caused by begomo viruses, which is transmitted by whitefly, Bemesia tabaci. The absence of resistant/tolerant sources against MYMV disease leads to tremendous crop yield losses. To identify the sources of resistance in mungbean against MYMV and to utilize in further breeding programme, $115 \mathrm{BC}_{2} \mathrm{~F}_{1}$ lines were screened under natural conditions and categorized into different reaction groups using rating scale against MYMV. In the current study, the screened lines were also re-evaluated under green-house conditions using agroinoculation screening technique in order to confirm the sources of resistance against MYMV disease incidence. Out of them, 10 were categorized as resistant (R) in field level screening and 6 were re-confirmed through agroinoculation screening. These results can be further utilized to validate the molecular markers to facilitate markerassisted selection for the development of MYMV resistant breeding lines.

\section{Introduction}

Pulses are mean to rich sources of quality protein comes under the family Fabaceae. The pulse cultivation accounts for about 32 per cent of the area and 23 per cent of the production around the world. Apart from its nutritional security pulses also play a major role in symbiotic nitrogen fixation by the beneficial soil bacterium Rhizobium spp., through crop rotation (Senanayake et al., 1987 and Zapata et al., 1987). Among pulses, mungbean (Vigna radiata (L.) Wilczek) known as green gram is one of the major fastgrowing, warm-season crop that is primarily cultivated in developing countries of Asia for their rich source of quality proteins, vitamins and minerals. Despite of its importance, the crop undergo several production constrains due to climatic changes, pest /disease 
problems and macro/ micronutrients deficiencies. Among them, viral diseases are widely devastating and cause heavy yield losses (Paul et al., 2013) and the most important damage amongst the virus is Mungbean Yellow Mosaic Virus (MYMV) which belongs to begomovirus, the largest genus of the family Geminiviridae (Dhakar et al., 2010) that are transmitted by white fly (Bemisia tabaci) (Sidhu et al., 2009). MYMV is made up of bipartite genome which consists of DNA A and DNA B respectively. The genomes of Gemini viruses can undergo high levels of mutation, recombination and reassortment to increase viral diversity (Duffy et al., 2008; Harkins et al., 2009; Martin et al., 2011; Lima et al., 2012).

The first occurrence of mungbean yellow mosaic virus (MYMV) was spotted by Nariani in 1960's. A typical MYMV symptom includes the presence of mosaic pattern that exist in the form of alternate green and yellow patches on the leaves, reduction in floral size and production of shrivelled seeds (Habib et al., 2007). Development of MYMV resistant mungbean cultivars has long been a major objective in disease resistance mungbean breeding. MYMV field screening procedures for identification of resistance has been shown to be largely inefficient, as many plants escape infection, even under heavy inoculation pressure (Vidaysky et al., 1998). Since a reliable laboratory screening protocol for assessing resistance/susceptibility of mungbean accessions against MYMV, was founded out to be new innovative technique called "Agroinfection" developed by Rogers et al., (1986). With the above background, in the present study, backcross lines obtained from mungbean parents were screened under natural conditions and were re-evaluated under greenhouse conditions, in order to identify the resistant sources to be used further in breeding programs.

\section{Materials and Methods}

\section{Plant materials}

Plant materials obtained from previous breeding programme namely $\mathrm{BC}_{2} \mathrm{~F}_{1}$ derived from the cross [VRM $\left(\mathrm{Gg} 1 \mathrm{x}^{\mathrm{BC}} \mathrm{BC}_{1} \mathrm{~F}_{1}\right.$ (VRM (Gg1) $\mathrm{x}$ VGGRU1)] were utilized in this study. VGGRU 1 is an interspecific derivative developed from the cross between mungbean and rice bean which is a resistant one and VRM (Gg) 1 is a susceptible variety of mungbean that is highly prone to MYMV.

Previously crosses has been generated to introgress the MYMV segment (chromosome loci which consist of resistance) from VGGRU1 to VRM (Gg) 1.In the present study the breeding materials generated were screened for MYMV resistance using infector row technique and were confirmed further.

\section{Field experiment}

$115 \mathrm{BC}_{2} \mathrm{~F}_{1}$ lines developed from the crosses [VRM (Gg1) $\quad \mathrm{X} \quad \mathrm{BC}_{1} \mathrm{~F}_{1} \quad(\mathrm{VRM} \quad(\mathrm{Gg} 1) \quad \mathrm{x}$ VGGRU1)] were evaluated in randomized complete block design along with their parents. All the recommended cultivation packages were followed except spraying of plant protection chemicals such that the whitefly population can be maintained.

In our study the parent 'VRM (Gg1)' is itself a highly susceptible cultivar, hence it was used as spreader row for MYMV infection. Every row of backcross lines were alternated with cultivar 'VRM (Gg) 1'.

The individuals were screened for resistance to MYMV under field condition using 1-9 scale rating (Singh et al., 1992) (Table 1). Seeds were harvested from the lines which showed maximum resistance to MYMV was used for further green house screening. 


\section{Green house screening using agroinoculation}

The infectious clone constructed from MYMV genome named VA 239 (KA30 DNA A + KA27 DNA B) obtained from Balaji et al., (2004) was used in this study for screening. Agroinoculation was done on 2 days old sprouted seeds of field resistant lines by protocol suggested by Jacob et al., (2003). Agroinoculated plants were maintained in a growth chamber at $25{ }^{\circ} \mathrm{C}$ with $60-70 \%$ of relative humidity for a photoperiod of $16 / 8$ h.Twice a week for proper growth and development, the plants were sprayed with Hoagland's solution. After 15th day from inoculation the symptom appearance was recorded in the trifoliate leaves. The occurrence of yellow mosaic symptoms at a given point in time was scored as susceptible and the nonappearance was scored as resistance against the disease. The uninoculated plants of each line were maintained as control. The experiment was repeated across replications.

\section{PCR confirmation}

The infectivity was checked by PCR assay using coat protein gene specific primer of
MYMV (FP1 5'GCGGAATTACGATA CCGCC3' and RP1 5'GATGCATGAG TACATGCC3') (Richa Maheswari, 2009) by using the temperature cycles as follows: $5 \mathrm{~min}$ at $94^{\circ} \mathrm{C}$ followed by 35 cycles of $1 \mathrm{~min}$ at $94^{\circ} \mathrm{C}, 1 \mathrm{~min}$ at $56^{\circ} \mathrm{C}$ and $1 \mathrm{~min}$ at $72^{\circ} \mathrm{C}$. The final elongation step was extended to $10 \mathrm{~min}$ at $72^{\circ} \mathrm{C}$ and finally maintained at $4^{\circ} \mathrm{C}$. The amplicons were observed on ethidium bromide pre-stained $1.2 \%$ agarose gel and are visualized on Alpha Imager 1200 (Alpha Innotech Corp., USA).

\section{Results and Discussion}

In the present investigation, an attempt was made to identify MYMV incidence and scoring was recorded in the field periodically for the resistance or susceptibility against MYMV from initial flowering to harvesting by weekly intervals. The scorings were done using 0-9 disease rating scale. Yellow mosaic disease were observed to be on 25-30 days after planting in the spreader row along with the backcross check lines under natural conditions. As a start small yellow specks of mild intensity were observed on young leaves and later transformed into alternate yellow and green patches with irregular margins.

Table.1 Rating scale used for scoring against Mungbean yellow mosaic virus (MYMV)

\begin{tabular}{|c|c|c|}
\hline Rating & Percentage foliage affected & Infection category \\
\hline 1 & $\begin{array}{l}\text { No visible symptoms or minute yellow specks covering } \\
0.1-5 \% \text { leaf area }\end{array}$ & Resistant (R) \\
\hline 3 & Mottling of leaves covering $5.1-15 \%$ leaf area & Moderately resistant (MR) \\
\hline 5 & $\begin{array}{l}\text { Yellow mottling and discoloration of } 15.1-30 \% \text { leaf } \\
\text { area }\end{array}$ & Moderately Susceptible (MS) \\
\hline 7 & $\begin{array}{l}\text { Pronounced yellow mottling and discoloration of leaves, } \\
\text { pods reducing in leaf size, stunting of plants, } 30.1-75 \% \\
\text { foliage affected }\end{array}$ & Susceptible (S) \\
\hline 9 & $\begin{array}{l}\text { Severe yellow mottling and discoloration of leaves, } \\
\text { stunting of plants, failure of flowering and fruit setting } \\
75.1-100 \% \text { foliar affected }\end{array}$ & Highly susceptible (HS) \\
\hline
\end{tabular}


Table.2 The resistant lines which were observed after agroinoculation and field level screening

\begin{tabular}{|c|c|c|c|c|}
\hline S.no & $\begin{array}{c}\text { Total no of } \\
\text { lines }\end{array}$ & Lines & $\begin{array}{c}\text { Infection } \\
\text { category }\end{array}$ & $\begin{array}{c}\text { Field/ } \\
\text { Agroinoculated }\end{array}$ \\
\hline $\mathbf{1}$ & 10 & $5,16,18,26,54,72,80,81,95,112$ & Resistant $(\mathrm{R})$ & Field \\
\hline $\mathbf{2}$ & 6 & $5,16,18,26,80,95$ & Resistant $(\mathrm{R})$ & Agroinoculated \\
\hline
\end{tabular}

Fig.1 PCR amplification of agroinoculated lines using CP gene specific primer. From left to right 1 - $1 \mathrm{~Kb}$ ladder, 2 to 11- lines which are field resistant chosen for agroinoculation screening (lines were mentioned in Table 2)

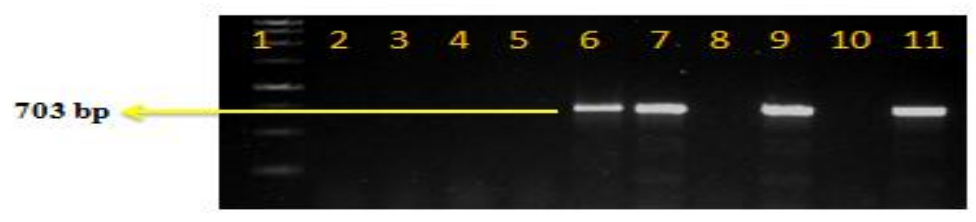

The disease severity increased with the passage of time. During field screening resistant response against MYMV was observed in 10 lines (Table 2), while on contrast 32 lines showed moderately resistant response, 54 lines displayed susceptible response and 9 lines were found to exhibit high susceptibility response against MYMV. Similar results were also substantiated by Mohan et al., (2014) and Manivannan et al., (2001).

The lines which were scored as resistant during field level screening were taken into agroinoculation screening. On agroinoculation contrast results were found to be seen. Among the 10 resistant lines 4 were found to be moderately susceptible. Symptoms were found to seen on those lines in three leaves after 15-17 days from the date of sowing. The above results clearly indicated that some of the "field-resistant" lines were found to be susceptible in agroinoculation. The resistance exhibited at the field level may be due to some mechanisms which prevent the entry of the virus through insect vectors.
The bottleneck under field conditions is that, the natural infection may not produce accurate results even if the fields are surrounded with high vector populations due to environmental factors. The level of infectivity of these field-resistant genotypes after agroinoculation ranged between 0 to 100 percent. The representative lines which are resistant in agroinoculation screening are shown in (Table 2).

Usharani et al., (2005) conducted infectivity analysis of Mungbean yellow mosaic virus in soybean isolate by agroinoculation and obtained similar results, i.e. about 70-95 percent infectivity of MYMV which is similar to the present study. The agroinoculated lines were subjected to PCR confirmation using CP gene specific primers and correlating to the above result, amplification was also seen only on the lines which were found to susceptible (Fig. 1).

Hence, concluded, on future prospects the obtained resistant lines might be utilized as parents for the upcoming breeding 
programmes to facilitate marker-assisted selection for the development of MYMV resistant breeding lines.

\section{Acknowledgement}

We thank the Department of Science and Technology, SERB, India for funding and supporting the research programme (YSS/2015/000321). We are also grateful to Dr K. Veluthambi, Madurai Kamaraj University, Tamil Nadu, India, for providing the Agrobacterium strains for our research.

\section{References}

Balaji, V., R.Vanitharani, A.S. Karthikeyan, S. Anbalagan and Veluthambi K. 2004. Infectivity analysis of two variable DNA B components of Mungbean yellow mosaic virus-Vigna in Vigna mungo and Vigna radiata. $\mathrm{J}$. Biosci. 29, 297-308.

Dhakar, V.K. Gupta, M.S. Rathore and Gaur R.K. 2010. Virus resistance and gene silencing in plants infected with begomovirus. Journal of Applied Sciences, 10: 1787-1791.

Duffy, S., and Holmes, E.C. 2008. Phylogenetic evidence for rapid rates of molecular evolution in the singlestranded DNA begomovirus tomato yellow leaf curl virus. Journal of Virology. 82: 957-965.

Habib, S., N.Shad, A. Javaid and Iqbal U. (2007). Screening of mungbean germplasm for resistance/tolerance against yellow mosaic disease. Mycopath, 5(2), 89-94.

Harkins, G.W., W. Delport, S. Duffy, N. Wood, A.L. Monjane, B.E.Owor, Donaldson,S. Saumtally and Triton G. 2009. Experimental evidence indicating that mastreviruses probably did not codiverge with their hosts. Journal of Virology. 6:104.
Lima, A.T.M., R.R. Sobrinho, A.J Gonza'lez, C.S. Rocha, S.J.C. Silva, C.A.D. Xavier, F.N. Silva, S. Duffy and Zerbini F.M. 2012. Synonymous site variation due to recombination explains higher variability in begomovirus populations infecting non-cultivated hosts. Journal of General Virology. 94: 418-431.

Manivannan, N., K. Sethuraman and Natarajan S. 2001. Screening of green gram (Vigna radiata (L.) Wilczek) germplasm for yellow mosaic resistance. Legume Res. 24: 268-271.

Mohan, S., A. Sheeba, E. Murugan and Ibrahim S. M. 2014. Screening of mung bean germplasm for resistance to MYMV under Natural Condition. Indian J. of Sci. and Technol.7: 891896

Nariani, T.K. 1960. Yellow mosaic of mungbean. Indian Phytopathology. 13: 24-29.

Paul, P.C., M.K. Biswass, D. Mandal and Paul P. 2013. Studies on host resistance of mungbean against mungbean yellow mosaic virus in the agro-ecological condition of lateritic zone of west Bengal. The Bioscan. 8(2): 583-587.

Richa Maheswari, 2008. DNA fingerprinting of Mungbean yellow mosaic virus (MYMV) affecting pulses. M.Sc Thesis, TamilNadu Agri. Univ. pp48.

Rogers, S. G., D. M. Bisaro, R. B. Horsch, R. T. Fraley, N. L. Hoffmann, L. Brand, J. S. Elmer and A. M. Lloyd. 1986. Tomato golden mosaic virus A component DNA replicates autonomously in transgenic plants. Cell. 45: 593 - 600.

Senanayake, L., D.P. Knievel and Stevena S. E.1987. Nodulation and symbiotic nitrogen fixation of cowpea (Vigna unguiculata L.). Plant and Soil. 99: 435-439. 
Sidhu, J.S., R.S. Mann and N.S. Butter. 2009. Deleterious effects of cotton leaf curl virus on longevity and fecundity of whitefly, Bemisia tabaci (Gennadius). J. Entomol. 6, 62-66.

Singh, G., Y.R. Sharma, and Kaur L. 1992. Method of rating mungbean yellow mosaic virus in mungbean and urdbean. Plant Disease Research. 7: 16.

Usharani, K.S., B. Surendranath, Q.M.R. Haq and Malathi V.G.2004. Yellow mosaic virus infecting soybean in northern
India is distinct from the species infecting soybean in southern and western. India Curr. Sci. 86, 845-850.

Vidavsky, F. and Czosnek, H. 1998. Tomato breeding lines resistant and tolerant to tomato yellow leaf curl virus issued from Lycopersicon esculentum. Phytopathology. 88: 910-914.

Zapata, F., S.K.A. Danso, G. Hardarson and Fried M. 1987. Nitrogen fixation and translocation in field-grown fababean. Agronomy Journal. 79: 505-509.

\section{How to cite this article:}

Madhumitha, B., K. Eraivan Arutkani Aiyanathan, M. Kanimoli Mathivathana and Sudha, M. 2019. Field and Agroinoculation Screening for Resistance against MYMV in Mungbean Backcross Populations. Int.J.Curr.Microbiol.App.Sci. 8(04): 2154-2159. doi: https://doi.org/10.20546/ijcmas.2019.804.252 